УДК 355.233

Михайло Орда, кандидат технічних наук, старший науковий співробітник Національний університет оборони України імені Івана Черняховського, м. Київ ORCID ID 0000-0003-0374-3881

Михайло Черненок, Національний університет оборони України імені Івана Черняховського, м. Київ ORCID ID 0000-0001-5376-6606 Лариса Левицька

Національний університет оборони України імені Івана Черняховського, м. Київ ORCID ID 0000-0001-6575-9964

DOI: $10.33099 / 2617-1775 / 2021-02 / 182-193$

\title{
НОРМАТИВНО-ПРАВОВЕ ЗАБЕЗПЕЧЕННЯ ПОБУДОВИ СИСТЕМИ ЗБОРУ ТА ОБРОБКИ ІНФОРМАЦІЇ ЩОДО ОЦНЮЮВАННЯ ЯКОСТІ ОСВІТИ ВИПУСКНИКІВ ВВНЗ, ГАРМОНІЗОВАНОЇ ІЗ СУЧАСНИМИ ПІДХОДАМИ У ДЕРЖАВАХ-ЧЛЕНАХ НАТО
}

Досліджено питання нормативно-правового забезпечення побудови системи збору та обробки інформації щьоо оцінювання якості освіти за підсумками службової діяльності випускників ВВНЗ, гармонізованої із сучасними підходами у державах - членах НАТО.

Ключові слова: нормативно-правовий акт; система збору та обробки інформачії щзодо оцінювання якості освіти; вищий військовий навчальний заклад; професійний стандарт; компетентність; оцінювання; службова діяльність; випускник.

\section{Постановка проблеми.}

Збройна агресія Російської Федерації проти України стала довгостроковим чинником, який вплинув на всі сфери життєдіяльності нашої країни. Дії Росії продовж останніх років призвели до різкої деформації системи глобальної та регіональної безпеки, а також фактично зруйнували діючу систему міжнародного безпекового права. Майже всі міжнародні гарантії безпеки для України виявилися нездатними протистояти агресії, коли агресором виступив один із гарантів - Російська Федерація.

Разом 3 тим, ми отримали гіркий, але безцінний досвід організації в найкоротші терміни і здійснення відсічі більш потужній країні-агресору, яка використовуючи чисельну “п'яту колону”, заздалегідь розгорнуту агентурну мережу та складну внутрішньополітичну ситуацію, намагалася втягнути Україну у довготривалу війну. Врахування зазначеного досвіду у ході подальшого реформування 3С України потребує ретельного аналізу їх застосування, а перш за все - удосконалення системи військової освіти та підготовки кадрів.

На підставі Указу Президента України № 473/2021 "Про рішення Ради національної безпеки і оборони України від 17 вересня 2021 року "Про Стратегічний оборонний бюлетень України" організовано роботу щодо 
досягнення перспективної моделі сил оборони та набуття визначених оборонних спроможностей здійснюватиметься 3 урахуванням актуальних та потенційних воєнно-політичних загроз і викликів та ресурсних можливостей шляхом імплементації таких стратегічних цілей розвитку сил оборони, сформульованих на основі визначених у Стратегії воєнної безпеки України цілей, пріоритетів і основних завдань реалізації державної політики у воєнній сфері, сферах оборони i військового будівництва та основних напрямів реалізації воєнної політики України $[1,2]$.

Однією з стратегічних цілей розвитку сил оборони є: професійний та вмотивований особовий склад сил оборони, підготовлений військовий резерв, що підтримуються за рахунок ефективних прозорих систем кадрового менеджменту, військової освіти і науки, охорони здоров'я і соціального захисту.

Результатом розвитку систем військової освіти, воєнної науки та підготовки особового складу на основі принципів і стандартів НАТО, підготовки за євроатлантичними стандартами офіцерського, сержантського та старшинського складу стануть трансформовані на основі принципів і стандартів НАТО системи військової освіти, підготовки і воєнної науки.

В Указі Президента України "Про цілі сталого розвитку України на період до 2030 року” зазначено, що “сучасна філософія освіти, оновлена стратегія їі реформування вимагають принципово нових наукових досліджень, обгрунтованого та послідовного запровадження передових науковопедагогічних технологій, раціональних і ефективних підходів до організації наукової та інноваційної діяльності у сфері освіти”'[3,4].

Основними показниками якості підготовки військових фахівців $є$ рівень сформованості у них певних компетентностей, їх відповідність вимогам стандарту вищої військової освіти за певною спеціальністю та професійного стандарту за визначеними у ВВНЗ спеціалізаціями.

Створення цілісної системи освітнього (педагогічного) оцінювання дозволяє постійно знати стан, проблеми навчання, своєчасно на них реагувати, прогнозувати перспективи розвитку освіти, досліджувати закономірності забезпечення якості освіти, освітньої діяльності, оцінювати ефективність прийнятих управлінських рішень, здійснювати підготовку, перепідготовку та ротацію керівних кадрів і науково-педагогічних працівників.

Досвід свідчить, про об'єднання зусиль різних країн у розробленні єдиних підходів до оцінки результатів навчання i проведенні міжнародних порівняльних досліджень, які дають цінну інформацію про стан освіти, дають можливість порівнювати підготовку фахівців за міжнародними стандартами, здійснювати моніторинг якості освіти. Незалежні експертні організації проводять зовнішнє оцінювання, розроблення критеріальної бази, контрольновимірювальних матеріалів, процедур оцінювання, складання рейтингів освітніх закладів, підготовку експертів і т. п. Обов'язковою рисою систем зовнішньої оцінки якості освіти є їхня відкритість і прозорість, доступність результатів для зацікавлених осіб і організацій. Надійна інформація про якість освіти стає у сучасному світі виробничим ресурсом, а в основу успішних стратегій управління якістю навчання закладають три базових елементи: широкий погляд 
на освітні результати і поєднання різних методів оцінки освітніх досягнень, якість освітніх програм і ефективність освітнього процесу.

Аналіз останніх досліджень і публікацій. Засади оцінювання освітньої діяльності розробляють О. Боднар, Н. Стребкова та ін. В. Погрібна і В. Мальцев визначають набір принципів, на основі яких будується система критеріїв оцінювання. Науковим інтересом дослідників, як С. Альохіна, Б. Вінницький, О. Кузьмін, М. Лендьєл, О. Мазурик, Ю. Ратейчак, І. Санжаровський, являються питання моніторингу та оцінювання освітніх програм. Значний внесок в оцінювання якості внесено закордонною науковою школою на чолі 3 Керолом Вайсом [5].

Наукові результати були отримані в ході проведення досліджень у рамках виконання науково-дослідних робіт: шифр “Сирена” (№ 0120U000211) та шифр “Сирена-М” (№ 0121U000121).

Мета статті - дослідження проблематики та нормативно-правових актів 3 питань побудови системи збору та обробки інформації щодо оцінювання якості освіти випускників ВВНЗ, гармонізованої із сучасними підходами у державахчленах НАТО.

Методи дослідження - аналіз нормативно-правових актів, принципи військово-технічного аналізу, системного аналізу, методи порівняння та аналогії, узагальнення й систематизації теоретичних знань; а також методи ідеалізації та абстрагування.

Виклад основного матеріалу. В контексті переходу на перспективну освітню модель, що визначається компетентнісним спрямуванням та спільною відповідальністю стейкхолдерів за якість вищої освіти, набувають особливої уваги питання оцінювання результатів освіти і підготовки випускників ВВНЗ та ВНП ЗВО за підсумками службової діяльності.

До основних нормативно-правових актів (директив, політик та інших офіційних керівних документів) з питань, що визначають на сьогодні політику у сфері військової освіти і підготовки військових фахівців для збройних сил країн-членів НАТО віднесені [6]:

1. Спільна директива стратегічних командувань НАТО (від 10.09.2015) “Освіта та індивідуальна підготовка”(Bi-SCD 075-007)”.

2. Директива НАТО від 06.09.2016 Bi-SCD 075-002 “Освіта і підготовка"

3. МС 0458/3 "Політика НАТО: “Освіта. Підготовка. Навчання і Оцінювання (ЕTЕE)"

4. Report to the Ranking Minority Member, Committee on Armed Services, House of Representatives - Звіт для комітету з питань діяльності збройних сил НАТО, палата представників.

5. Officer professional military education policy. "Політика професійної військової освіти офіцерів", від 29 травня 2015 року.

6. Army Regulation (AR) 623-3, Evaluation Reporting System - "Настанова Сухопутних військ щодо системи атестування".

У зазначених документах визначаються основні складові системи освіти і підготовки військових фахівців збройних сил країн-членів НАТО, розкривається їх змістовне наповнення, зокрема: освіта та індивідуальна 
підготовка; колективна підготовка та навчання (вправи).

Крім того:

надаються роз'яснення щодо сумісності дій у досягненні оперативних та стратегічних цілей, а також щодо компонентів взаємодії та цілісного підходу до питань освіти і підготовки військових фахівців (в рамках спектру підготовки виділено два основні елементи це: а) освіта; б) індивідуальне навчання та підготовка);

наводяться дані, які стосуються саме зворотного зв'язку в системі підготовки військових фахівців для збройних сил НАТО, а саме з питань щодо механізмів зворотного зв’язку; а також “джерел” для оцінювання актуальності навчальних програм професійної військової освіти, їх якості та дієвості;

роз'ясненюються питання щодо оцінювання професійної військової освіти на усіх рівнях військової освіти в процесі проведення періодичного оцінювання (за підсумками таких перевірок визначаються загальні напрямки, що потребують покращення для забезпечення актуальності та дієвості професійної військової освіти);

надаються окремі витримки та наводяться деякі форми документів, що стосуються зворотного зв'язку в системі підготовки військових фахівців збройних сил НАТО, а саме:

у витязі з Настанови Сухопутних військ щодо системи атестування наводиться форма (КАРТКА СЛУЖБОВОЇ АТЕСТАЦІЇ ОФІЦЕРА МОЛОДШОГО ОФІЦЕРСЬКОГО СКЛАДУ), заповнюється на офіцерів у військовому званні від молодшого лейтенанта до капітана та від уорент-офіцера до старшого уорент-офіцера;;

у Сухопутних військах США загальнопоширеною є практика заповнення усіх полів атестаційної картки офіцера за допомогою програми Майстра заповнення форм з електронним варіантом форми, розміщеним у системі обліку атестації, постановки цифрових підписів та електронного подання заповненої картки атестації офіцера до штабу командування сухопутних військ.

В системі оцінювання 3С України акцент зроблено на оцінювання фактичних рівнів оволодіння фаховими теоретичними знаннями та практичними уміннями за час перебування на займаній посаді. Висновок щодо можливості службового просування офіцера робиться на основі оцінки рівня засвоєння офіцером тих знань і навичок, які були необхідні при перебуванні на займаній ним посаді.

В системі оцінювання NATO пріоритет надано виявленню наявності та рівня розвитку тих природних здібностей i якостей, які $є$ важливими для можливості ефективного освоєння необхідної військової спеціальності. І тільки після цього оцінюється наскільки ефективно, повно та добросовісно військовослужбовець використовує свої природні здібності для освоєння та виконання службових обов'язків відповідно до займаної посади. Фахові знання та уміння при цьому майже не розглядаються - адже для кожної посади застосовується обмежений та вузькоспеціалізований набір знань та умінь, специфічних саме для цієї посади та непридатних для інших посад. Висновок щодо можливості службового просування офіцера робиться на основі того, як 
ефективно офіцер здатний застосувати свої природні здібності для швидкого і ефективного освоєння нового виду діяльності. При цьому результати, досягнуті офіцером за попередніми та поточними видами його діяльності розглядаються як підтвердження його уміння застосовувати свої природні здібності для вирішення практичних задач.

Порівнюючи, система оцінювання ЗС України робить висновок по факту досягнутого. Система оцінювання NATO робить висновок із прогнозу можливості досягнути в недалекій перспективі (при цьому при прогнозуванні робиться поправка на фактичні досягнення, 3 врахуванням можливостей їх отримати відповідно до умов перебування на посадах).

В цілому, система оцінювання і відбору кадрів NATO спрямована на виявлення військовослужбовців, які здатні швидко сприймати зміни та адаптуватись до них, швидко сприймати нововведення та способи їх застосування, здатні знаходити шляхи вирішення поставлених задач у нетипових обставинах, здатні надихати та мотивувати очолювані ними підрозділи, здатні створювати командну атмосферу та злагоджену роботу підрозділів у дусі єдності та взаємовідповідальності. Анкета NATO не місить питань щодо оцінювання рівня фахових знань та вмінь військовослужбовця. Анкета NATO спрямована на оцінювання рівня розвитку тих природних здібностей, які важливі для освоєння відповідної військової спеціальності.

Недоречним місцем системи оцінювання ЗС України $є$ паралельне існування двох анкет - Оцінної картки військовослужбовця та анкети Відгуку на випускника. Анкета випускника, в основному, містить перелік питань щодо оцінки рівня засвоєнні різних навчальних дисциплін у навчальному закладі. Причому, оцінку повинен робити безпосередній командир випускника. Причому, у службовій діяльності на займаних посадах ні у командира, ні у випускника немає службової потреби застосовувати повний перелік навчальних дисциплін. В силу цього ні командир, ні випускник не мають потреби утримувати ці знання у активному стані. Складається ситуація, коли графу в анкеті необхідно заповнити, а необхідної для цього інформації не існує.

3 анкетою випускника $є$ ще суттєва проблема - спеціальностей багато, посад ще більше. Якщо будувати анкету по принципу переліку навчальних дисциплін, то, для забезпечення принципу об'єктивності і справедливості під кожну посаду необхідно розробляти спеціалізовану анкету, а це приводить до необгрунтованого надлишкового паперотворення. I ще одне - командира цікавить як випускник справляється 3 освоєнням і виконанням покладених на його обов'язків, а не глибина засвоєння ним окремих навчальних дисциплін. Оцінка якості виконання обов'язків міститься у Оцінній картці військовослужбовця. Отже, існування Анкети випускника є надлишковим, необгрунтованим і недоцільним. Від іiі застосування необхідно відмовитись.

Вищі військові навчальні заклади повинні знайти способи будувати свої навчальні плани та коригувати їх без застосування анкети випускника.

Порівняння - Картка службової атестації офіцера молодшого офіцерського складу NATO займає 2 сторінки, причому половина площі відводиться для поміщення інформації про осіб, які проводили оцінювання/атестування 
офіцера.

Анкета випускника займає 4 сторінки, із яких майже 3 призначені для виставлення оцінок за різні навчальні дисципліни.

Оцінна картка військовослужбовця (скорочена) за обсягом відповідає Картці службової атестації офіцера молодшого офіцерського складу NATO, але при цьому вона містить тільки перелік фактичних досягнень та не дає можливості оцінити чи спрогнозувати перспективні напрямки використання військовослужбовця.

Таким чином, система оцінювання 3С України бере до уваги фактичний рівень компетентності особи у дорученій ій вузькій сфері діяльності. Система оцінювання NATO бере до уваги спроможності особи щодо швидкого досягнення необхідного рівня компетентності у достатньо широкій сукупності можливих (чи бажаних командуванню) сфер діяльності. Інакше кажучи система відбору кадрів NATO діє по принципу “для кожної задачі - свій інструмент". Система відбору кадрів ЗС України орієнтована на оцінку можливості вирішення широкого кола різних задач одним i тим самим інструментом. Ідея універсального інструменту цікава, але життєвий досвід каже, що застосування кількох вузькоспеціалізованих інструментів дає кращий результат, аніж спроба зробити все одним універсальним інструментом.

В той же час у військовій справі є звичайним явищем, коли ситуація складається так, що скористатись набором вузькоспеціалізованих інструментів по різних причинах неможливо i тоді поставлену задачу приходиться вирішувати тим, що є. В цьому сенсі військовослужбовець-“multi-tool” має відповідні переваги.

I навіть у цьому випадку підхід NATO дозволяє попередньо виявити тих, хто має здатність стати таким -“multi-tool” і відбирати їх для вирішення відповідного кола задач. В цілому, система оцінювання NATO розглядається як більш гнучка й ефективна - вона дозволяє при менших трудовитратах отримати більш актуальну інформацію для прийняття кадрових рішень, ніж система оцінювання 3С України. Оскільки в ЗС України та в NATO різні принципи підходу до побудови системи оцінювання військовослужбовців, то виникає питання як досягти спільного знаменника 3 врахуванням вимоги "гармонізації системи оцінювання ЗС України з системою оцінювання NATO”.

Як варіант повної "гармонізації" $\epsilon$ повне впровадження системи оцінювання NATO. При цьому буде необхідно видати ряд нових наказів та розпоряджень Міністерства оборони України та скасувати/змінити цілий ряд діючих наказів та розпоряджень.

На нашу думку, існування одночасно двох анкет в системі оцінювання ЗС України - Оцінної картки та Відгуку на випускника недоцільно.

Тому, 3 урахуванням вищевикладеного, питання щодо розв'язання зазначеної проблеми, а саме того, що стосується надання загальної характеристики системи $3 \mathrm{OI}$ щодо оцінювання якості освіти випускників ВВН3 за підсумками їх службової діяльності у ЗСУ та збройних силах держав-членів НАТО, розглянемо через площину результатів системного аналізу ряду нормативних (керівних) документів щодо професійної військової освіти 
держав - членів НАТО, результатів аналізу систем військової освіти провідних країн-членів НАТО та “кроків” України з цих питань та модернізації військової освіти і заходів співробітництва у сфері освіти між Міністерством оборони України та держав - членів НАТО [7-9].

Результати проведеного аналізу використання систем збору та обробки інформації щодо оцінювання якості освіти випускників ВВНЗ за підсумками їх службової діяльності у Збройних Силах України і збройних силах державчленів НАТО, нормативно-правових актів (документів) щодо зазначеної проблематики, 3 метою підвищення ефективності функціонування системи оцінювання та набуття системою професійної військової освіти спроможностей досягнення операційної сумісності на основі стандартів, прийнятих у збройних силах держав-членів НАТО, свідчать про необхідність внесення змін та доповнень до ряду нормативно-правових актів (документів) з питань оцінювання якості освіти випускників ВВНЗ.

Разом 3 тим, у деяких із них, навпаки, достатньо чітко висвітлені кардинальні зміни щодо структури системи військової освіти, і не потребують доопрацювання, та/або внесення змін чи доповнень. Низка із них, відповідає вимогам щодо побудов сучасної моделі професійної військової освіти України та прагненням щодо набуття іiі операційної сумісності зі стандартами, прийнятими з збройних силах держав-членів НАТО.

До цього переліку віднесено:

Положення про особливості організації освітньої діяльності у ВВНЗ Міністерства оборони України та ВНП ЗВО", затвердженого наказом Міністерства оборони України від 09.01.2020 № 4;

Концепція військової кадрової політики Міністерства оборони України на період до 2025 року", затвердженої наказом Міністерства оборони України від 14.09.2021 № 280;

Методичні рекомендації з порядку організації і проведення атестування військовослужбовців Збройних Сил України, затверджені директором Департаменту кадрової політики Міністерства оборони України від 19.04.2017 № 328 (зі змінами від 12.10.2018 № 226/4907;

Інструкція про організацію виконання Положення про проходження громадянами України військової служби у Збройних Силах України, введеного в дію наказом Міністра оборони України від 10.04.2009 № 170.

Таким чином, за результатами аналізу нормативно-правових документів, якими охоплюється проблематика щодо оцінювання результатів навчання здобувачами відповідної освіти у ВВНЗ та ВНП ЗВО, у т.ч., за підсумками їх службової діяльності у Збройних Силах України, та питання щодо визначення документів, що потребують доопрацювання (доповнень та/або внесення відповідних змін), пропонується:

1. Розроблення нових форм відгуків на випускників ВВНЗ за усіма існуючими рівнями підготовки: тактичного, оперативного, стратегічного, а також курсів підготовки з урахуванням сучасних тенденцій щодо набуття випускниками ВВНЗ сучасної професійної військової освіти, а саме набуття нових ознак, якостей і відповідних спроможностей щодо операційної сумісності 
на основі стандартів, прийнятих у збройних силах держав-членів НАТО.

2. Відновлення надання (відображення) у відповідному додатку до Директиви Генерального штабу Збройних України від 06.03.2014 № ДГШ-6, "Про затвердження Табеля термінових донесень Збройних Сил України 3 кадрових питань та підготовки військових фахівців" нових форм відгуків на випускників ВВНЗ та ВНП ЗВО за усіма існуючими рівнями їх підготовки.

3. Внесення змін та доповнень до "Інструкції про організацію підготовки та проведення інспекційних заходів" (наказ Міністра оборони України від 21.07.2011 № 440) та Методики комплексної (поточної, часткової) перевірки, вивчення стану справ у вищих військових навчальних закладах та військових навчальних підрозділах вищих навчальних закладів" (наказ Міністерства оборони України від 08.09.2014 № 630).

Висновки. Відгук на випускника після року служби у військах розглядається як чи не єдиний інструмент зворотного зв'язку з питань оцінювання результатів навчання випускників та відповідного корегування освітнього процесу, решта форм зворотного зв'язку в кращому випадку просто згадуються в нормативно-правових та керівних документах але не мають юридично закріплених формалізованих алгоритмів використання.

Удосконалення підготовки кадрів і системи військової освіти дозволить підвищити якість теоретичної та практичної підготовленості особового складу до виконання обов'язків за посадами призначення. Буде завершено створення системи підготовки сержантського i старшинського складу. Безперервна підготовка кадрів, що органічно поєднує військову освіту, перепідготовку та підвищення кваліфікації, створить умови для постійного професійного розвитку особового складу, забезпечить його кар'єрне зростання протягом всієї служби та підтримання високої бойової готовності військ (сил).

3 метою вдосконалення системи військової освіти та підготовки кадрів для 3С України необхідно завершити приведення нормативно-правових актів Міністерства оборони України у галузі військової освіти до вимог законодавства України з урахуванням досвіду проведення Антитерористичної операції (операції Об'єднаних сил), подальше законодавче і нормативне врегулювання питань підготовки військових фахівців, гармонізоване із сучасними підходами у державах-членах НАТО.

Напрями подальших досліджень Напрямом подальших досліджень $є$ створення системи збору та обробки інформації щодо оцінювання якості освіти випускників ВВН3, гармонізованої із сучасними підходами у державах-членах НАТО, налагодження взаємного зв'язку замовник-виконавець на підставі створення єдиної бази даних та відповідного програмного забезпечення, у тому числі на платформі дистанційного навчання.

\section{ЛІТЕРАТУРА}

1. Указ Президента України від 25 березня 2021 року № 121/2021 “Про рішення Ради національної безпеки і оборони України від 25 березня 2021 року “ Про Стратегію воєнної безпеки України".

2. Указ Президента України від 17 вересня 2021 року №473/2021 “Про рішення Ради національної безпеки і оборони України від 20 серпня 2021 року "Про Стратегічний 
оборонний бюлетень України".

3. Указ Президента України “Про вдосконалення вищої освіти в Україні” (від 3.07.2020 № 210/2020).

4. Указ Президента України "Про цілі сталого розвитку України на період до 2030 року” (від 30 вересня 2019 р. № 722/2019).

5. Вайс К. Г. Оцінювання: методи дослідження програм та політики / Керол Г. Вайс ; пер. 3 англ. Р. Ткачука та М. Корчинської ; наук. ред. пер. О. Кілієвич. - Київ : Основи, 2000. $-671 \mathrm{c}$.

6. Вітер Д. Професіоналізація військової освіти в Україні: головні напрямки, зміст та перспективи / Військова освіта. - 2020 - № 1(41). С. 81-90.

7. Петренко О. О. Застосування методів "360 градусів" та "assessment-центру" для оцінки фахівців за компетентностями / О. О. Петренко // Проблеми економіки. - 2015. - № 4. C. 216-221. - Режим доступу: http://nbuv.gov.ua/UJRN/Pekon_2015_4_29.

8. Рекомендації Національного агентства із забезпечення якості вищої освіти стосовно запровадження внутрішньої системи забезпечення якості від 26.06.2019p. № 6. URL: https://osvita.ua/legislation/Vishya_osvita/77308.

9. Стандарти і рекомендації щодо забезпечення якості в Свропейському просторі вищої освіти. URL: https://www.britishcouncil.org.ua /sites/default/files/standards-andguidelines_for_qa_in_the_ehea_2015.pdf.

10. Наказ Міністерства оборони України від 26.06.2017 № 342 Концепція військової кадрової політики у Збройних Силах України на період до 2020 року [Електронний ресурс] Режим доступу : https://www.mil.gov.ua/ministry/normativno-pravova-baza/nakazi-ministraoboroni-ukraini.

11. Методичні рекомендації 3 порядку організації i проведення атестування військовослужбовців Збройних Сил України, затверджені директором Департаменту кадрової політики Міністерства оборони України від 19.04.2017 № 328 (зі змінами від 12.10.2018 № 226/4907).

12. Методичні рекомендації щодо підготовки відгуку на випускника вищого військового навчальною закладу Збройних Сил України (військового навчального підрозділу вищого навчального закладу) Толок І.В., Черних Ю.О., Приходько Ю.І., Зельницький А.М., Водолазський В.О., Поліщук Т.В.

13. Наказ Міністерства оборони України від 09.01.2020 року № 4 “Про затвердження Положення про особливості організації освітньої діяльності у вищих військових навчальних закладах Міністерства оборони України та військових навчальних підрозділах закладів вищої освіти, затвердженим наказом Міністерства оборони України" [Електронний ресурс] Режим доступу: https://www.mil.gov.ua/ministry/normativno-pravova-baza/nakazi-ministraoboroni-ukraini.

14. Указ Президента України від 10.12.2008 № 1153/2008 “Про Положення про проходження громадянами України військової служби у Збройних Силах України” (зі змінами).

\section{REFERENCES}

1. Decree of the President of Ukraine of March 25, 2021 № 121/2021 "On the decision of the National Security and Defense Council of Ukraine of March 25, 2021" On the Strategy of Military Security of Ukraine ".

2. Decree of the President of Ukraine of September 17, 2021 №473 / 2021 "On the decision of the National Security and Defense Council of Ukraine of August 20, 2021" On the Strategic Defense Bulletin of Ukraine ".

3. Decree of the President of Ukraine "On the improvement of higher education in Ukraine" (from 3.07.2020 № 210/2020).

4. Decree of the President of Ukraine "On the goals of sustainable development of Ukraine for the period up to 2030" (September 30, 2019 № 722/2019). 
5. Weiss KG Evaluation: research methods programs and policies / Carol G. Weiss; lane from English R. Tkachuk and M. Korchynska; Science. ed. lane O. Kilievich. - Kyiv: Osnovy, 2000. $671 \mathrm{p}$.

6. Viter D. Professionalization of military education in Ukraine: main directions, content and prospects / Military education. - 2020 - № 1 (41). Pp. 81-90.

7. Petrenko OO Application of "360 degrees" and "assessment-center" methods for assessment of specialists by competencies / OO Petrenko // Problems of economy. - 2015. - № 4. P. 216-221. - Access mode: http://nbuv.gov.ua/UJRN/Pekon_2015_4_29.

8. Recommendations of the National Agency for Quality Assurance in Higher Education regarding the introduction of an internal quality assurance system dated June 26, 2019. № 6. URL: https://osvita.ua/legislation/Vishya_osvita/77308..

9. Standards and recommendations for quality assurance in the European Higher Education Area. URL: https://www.britishcouncil.org.ua /sites/default/files/standards-andguidelines_for_qa_in_the_ehea_2015.pdf.

10. Order of the Ministry of Defense of Ukraine dated 26.06.2017 № 342 Concept of military personnel policy in the Armed Forces of Ukraine for the period up to 2020 [Electronic resource] Access mode: https://www.mil.gov.ua/ministry/normativno-pravova -base / orders-of-the-ministerof-defense-ukraine.

11. Methodical recommendations on the procedure for organizing and conducting certification of servicemen of the Armed Forces of Ukraine, approved by the Director of the Personnel Policy Department of the Ministry of Defense of Ukraine dated 19.04.2017 № 328 (as amended on 12.10.2018 № 226/4907).

12. Methodical recommendations for preparing a response to a graduate of a higher military educational institution of the Armed Forces of Ukraine (military educational unit of a higher educational institution) Tolok IV, Chernykh YO, Prikhodko YI, Zelnytsky AM, Vodolazsky V .O., Polishchuk TV

13. Order of the Ministry of Defense of Ukraine dated 09.01.2020 № 4 "On approval of the Regulations on the organization of educational activities in higher military educational institutions of the Ministry of Defense of Ukraine and military educational units of higher education institutions, approved by the order of the Ministry of Defense of Ukraine" [Electronic resource] Regime access: https://www.mil.gov.ua/ministry/normativno-pravova-baza/nakazi-ministraoboroni-ukraini.

14. Decree of the President of Ukraine of 10.12.2008 № 1153/2008 “On the Regulations on military service of citizens of Ukraine in the Armed Forces of Ukraine" (as amended).

\section{РЕЗЮМЕ}

Михаил Орда, кандидат технических наук, старший научный сотрудник

Национальный университет обороны Украины имени Ивана Черняховского

Михаил Черненок,

Национальный университет обороны Украины имени Ивана Черняховского

Лариса Левицька

Национальный университет обороны Украины имени Ивана Черняховского

\footnotetext{
Нормативно-правовое обеспечение построения системы сбора и обработки информации об оценивании качества образования выпускников ВВУЗ, гармонизированное с современными подходами в государствах-членах НАТО
} 
Исследован вопрос нормативно-правового обеспечения построения системы сбора и обработки информации об оченивании качества образования выпускников ВВУЗ по итогам служебной деятельности, гармонизированное с современными подходами в государствахчленах НАТО.

Ключевые слова: нормативно-правовой акт; система сбора и обработки информащии об оценивании качества образования; высшее военное учебное заведение; профессиональный стандарт; компетентность; оценки; служебная деятельность; выпускник.

\section{SUMMARY}

\section{Mikhailo Orda,}

$\mathrm{PhD}$ (technical sciences), Senior Researcher

National Defence University of Ukraine named after Ivan Chernyahovskyi

Mikhailo Chernenok

National Defence University of Ukraine named after Ivan Chernyahovskyi

Larysa Levitska

National Defence University of Ukraine named after Ivan Chernyahovskyi

\section{Kegulatory and legal provision of construction of the system of collection and processing of information regarding the assessment of the quality of education of graduate education institutions, harmonized with modern approaches in NATO member states}

The issue of regulatory and legal support for the construction of a system for collecting and processing information on assessing the quality of education of university graduates based on the results of official activities, harmonized with modern approaches in NATO member states, has been studied.

Key words: normative legal act; system of collecting and processing information on assessing the quality of education; higher military educational institution; professional standard; competence; assessments; service activities; graduate.

Introduction. The main indicators of the quality of training of military specialists are the level of formation of certain competencies, their compliance with the requirements of the standard of higher military education in a particular specialty and professional standard in the specialties identified in higher education.

Creating a holistic system of educational (pedagogical) assessment allows you to constantly know the state, problems of learning, respond to them in a timely manner, predict the prospects of education, explore the quality of education, educational activities, assess the effectiveness of management decisions, training, retraining and rotation of management and scientific and pedagogical workers.

Purpose. Research on issues and regulations on the construction of a system for collecting and processing information on assessing the quality of education of university graduates, harmonized with modern approaches in NATO member states.

Methods. analysis of normative-legal acts, principles of military-technical analysis, system analysis, methods of comparison and analogy, generalization and systematization of theoretical knowledge; as well as methods of idealization and abstraction.

Result. The results of the analysis of the use of information collection and processing systems to assess the quality of education of university graduates based on their service in the Armed Forces of Ukraine and the Armed Forces of NATO member states, regulations (documents) on this issue to improve the efficiency of the evaluation system and the acquisition by the military military education system of the ability to achieve interoperability on the basis of standards adopted by the armed forces 
of NATO member states, indicate the need for changes and additions to a number of regulations (documents) on assessing the quality of education.

Originality. The main problematic issues regarding the regulatory support for the assessment of educational results based on the results of the service activities of graduates of high military school of the Armed Forces are:

- the place of ensuring the quality of education as a systemic category requires the practical implementation of fundamentally new approaches in education management;

- there is no clear understanding of the stages of issues and regulations on the evaluation of educational results and training of graduates of high military school based on the results of official activity;

- there are no criteria for the relevant content and tools for the practical implementation in military education.

Addressing these issues is important and relevant given the improvement of the career development system of officers (service), achieving positive results in military education, forming a team of military professionals.

Conclusion. The direction of further research is to create a system for collecting and processing information on assessing the quality of education of university graduates, harmonized with modern approaches in NATO member states, establishing customer-based communication through the creation of a single database and software distance learning platform. 